\title{
'n Evaluering van personeelbestuurseffektiwiteit in agt boerdery-ondernemingstipes in die RSA landbou
}

\author{
L.K. Oosthuizen \\ Departement Landbou-ekonomie, Universiteit van die Oranje-Vrystaat, Posbus 339, BIoemfontein 9300, Republiek van Suid-Afrika
}

Received August 1994

\begin{abstract}
The aim with this study was firstly to determine the degree of discrepancy between the work experiences and work preferences of staff, on the one hand, and the prediction of the farmer in this regard on the other; and secondly, to analyse farmers' perceptions on efficient and inefficient personnel management practices. A Likert-type personnel management audit (PMA) was implemented in eight types of farming with 234 workers and eight farmers. In general, the effectiveness of the motivation, communication, work performance, staff control and leadership systems leaves room for improvement. The knowledge of the farmers in the case-studies as regards efficient and inefficient staff management systems can be improved considerably, especially their perceptions on the role of training in worker productivity and work satisfaction. With the necessary knowledge of management, the farmers can manipulate the human relations practices effectively. It ought to be determined to what degree consultative management systems are used on farms, while the staff members prefer participative personnel management practices.
\end{abstract}

Die doel van hierdie studie was eerstens om die graadverskille te bepaal tussen personeel se werkervarings en -voorkeure aan die een kant en die boere se voorspellings daarvan aan die ander kant; en tweedens om die boere se persepsies oor doeltreffende en ondoeltreffende personeelbestuurspraktyk te ontleed. ' $n$ Likert-tipe personeelbestuursoudit (PBO) is in agt boerderytipes op 234 werkers en agt boere uitgevoer. Oor die algemeen laat die effektiwiteit van die motivering-, kommunikasie-, werkprestasie-, personeelbeheer- en leierskapstelsels ruimte vir verbetering. Die gevallestudieboere se kennis ten opsigte van doeltreffende en ondoeltreffende personeelbestuurstelsels kan heelwat verbeter, veral hul persepsies ten opsigte van die rol van opleiding in werkerproduktiwiteit en werknemertevredenheid. Gegewe die nodige bestuurskennis, kan die boere die menseverhoudingspraktyke effektief manipuleer. Daar behoort vasgestel te word hoe algemeen konsulterende personeelbestuurstelsels op plase gebruik word, terwyl die personeel deelnemende personeelbestuurstelsels verkies.

\section{Inleiding}

Arbeid is 'n fundamentele hulpbron op plase en dit sal waarskynlik vir baie jare so bly omdat arbeid die katalisator is wat sinvolle reaksies tussen die onderneming se produksiefaktore laat plaasvind.

'The farm worker at his job is often the only form of power, instrumentation and decision-taking that exists on the spot. Thus by the way he observes and reacts so he governs not only the efficiency of his own application but that of all the other production resources which he controls' (Armstrong \& Lloyd, 1972: 4).

Vir doeltreffende en effektiewe bestuur behoort boere dus kennis te hê van menslike werkgedrag en hul personeel se persepsies oor hul werkomgewing.

Personeelbestuursdoeltreffendheid (om personeelbestuursfaktore reg te manipuleer) en personeelbestuurseffektiwiteit (om die regte personeelbestuursfaktore te manipuleer) kan met behulp van ' $n$ diagnostiese instrument soos die Likerttipe personeelbestuursoudit (PBO) wat deur Oosthuizen (1990) vir gebruik op laaggeletterde personeel aangepas is, gekwantifiseer word. Die PBO is 'n tegniek wat met behulp van die gevallestudiemetode uitgevoer word en behels eerstens dat personeel tot op die laagste geletterde vlak in die onderneming se persepsies oor personeelbestuur (PB) op 'n praktiese en betroubare wyse gekwantifiseer word; tweedens dat die werkgewer se persepsies oor PB ook gemeet word sodat bepaal kan word hoe effektief die werkgewer sy personeel se werkgedrag kan manipuleer; en derdens dat 'n stelselbenadering gevolg word by die diagnose van die personeelbestuurstelsel (PBS) (Oosthuizen \& Coetzee, 1991a).

Nege PBO's is die afgelope vyf jaar by 239 plaaswerkers in Transvaal, Natal en die Oranje-Vrystaat gedoen. Wat personeelbestuursdoeltreffendheid (PBD) betref, het Oosthuizen (1993: 1) bevind dat die werkers oor die algemeen konsulterende personeelbestuurstelsels ervaar, maar deelnemende stelsels verkies sodat PBD kan verbeter as die personeel groter deelname bekom in die praktyke ten opsigte van leierskap, motivering, kommunikasie, menseverhoudings, personeelbeheer en werkprestasie. Wat nog ontbreek, is 'n ontleding van personeelbestuurseffektiwiteit (PBE) waar die persepsies van beide werkgewer en werknemer oor personeelbestuurservarings en -voorkeure vergelyk word.

Die doel van hierdie studie was eerstens om die graadverskille te bepaal tussen personeel se werkervarings en -voorkeure aan die een kant en die werkgewers se voorspellings daarvan aan die ander kant; en tweedens om werkgewers se persepsies oor doeltreffende teenoor ondoeltreffende personeelbestuurspraktyke te ontleed.

\section{Personeelbestuurseffektiwiteit}

Personeelbestuurseffektiwiteit in die landbou is nie na wense nie omdat werkgewers se persepsies oor leierskap, motivering, kommunikasie, menseverhoudinge, personeelbeheer en werkprestasie in selfs die progressiefste boerderyondernemings grootliks verskil van die werknemers se werkervaringe en -verwagtinge oor personeelbestuur (Oosthuizen \& Coetzee, 1991b: 18). Indien geen of geringe verskille tussen die werknemers se persepsies oor hul werksituasie en die werkgewers se voorspellings daarvan voorkom, beteken dit dat die werkgewers die werkers goed verstaan en met goeie bestuur hul werkgedrag en werkmotivering effektief kan verander. Indien groot verskille bestaan, dui dit op teenproduktiewe kragte wat reggestel moet word. Die uitgangspunt is nie wie se persepsies reg of 
verkeerd is nie, maar waarom daar groot verskille bestaan. 'n Goeie bestuurder moet personeel se persepsies en gevolglik werkhoudinge effektief kan manipuleer ten einde hoër werkerproduktiwiteit en groter werktevredenheid in die onderneming te bewerkstellig.

Die navorsing wat in die landbou oor personeelbestuur gedoen is, het in die sestigjare gekonsentreer op arbeidsproduktiwiteitsmeting met behulp van mandagberekenings en arbeidsprofiele (Kassier, 1964), produksiefunksies (Kassier, 1966) en metode- en tydstudies (Graham \& Groenewald, 1969). In die 1970's was die fokus op doelwitbestuur (Hill, 1974) en tydbestuur (Parsons, 1978). Maar die rol van werkhoudings as ' $n$ belangrike bepaler van werkerproduktiwiteit in die landbou is net soos in ander Westerse lande grootliks geïgnoreer. Op streeksgrondslag is enkele studies uitgevoer waarin die stand van personeelbestuur beskryf is soos die navorsing van Louw (1969), Beyers (1971), Wilson, Kooy \& Hendrie (1977), Roodt (1980), Du Toit (1982), Antrobus (1984) en Robertson (1989), maar 'n diagnostiese tegniek waarmee werkhoudings gemeet en reggestel kan word, het ontbreek en slegs finansiële aansporingsmaatreëls is gebruik om personeel se werkhoudings en -gedrag te verbeter.

Eers in die tagtigerjare het Oosthuizen (1990: 93) Armstrong \& Lloyd (1972: 1-67) se benadering tot die meting van personeelbestuur op plase in Engeland aangepas vir gebruik in boerdery-ondernemings in ontwikkelende lande waar die werkers meestal ongeskoold en laaggeletterd is. Oosthuizen \& Radley (1991: 19) het bevind dat die aangepaste personeelbestuursoudit (PBO) se vrae op so 'n wyse saamgestel, gegroepeer en met behulp van 'n blok- en penapparaat aangebied kan word dat ongeskoolde en laaggeletterde plaaswerkers hul persepsies oor hul werkomgewing op 'n praktiese en betroubare wyse kan registreer. Wat egter nog ontbreek, is die uittoetsing van die PBO by verskillende boerderytipes oor ' $n$ wye gebied in die RSA om personeelbestuurseffektiwiteit te verbeter.

\section{Materiaal en metodes}

Die PBO's by nege verskillende boerderytipes, uitgesluit die Kaapprovinsie, dek 'n wye gebied in die RSA. Die boerderytipes sluit in: mielies (Transvaal), piesangs (Noord-Transvaal), tabak (Wes-Transvaal), bosbou (Natal), suikerriet (Natal), koring (Sentraal-Vrystaat), vee (Oos-Vrystaat) en melk (Noord-Vrystaat). In die geval van melkboerdery is slegs die werknemers se persepsies oor hul werksituasie gemeet maar nie die werkgewer se voorspelling van die personeel se werkervarings en -voorkeure nie - dit is dus vir hierdie gedeelte van die studie weggelaat. Die geselekteerde boerderytipes verteenwoordig die vernaamste gewas- en veevertakkings in die Suid-Afrikaanse landbou.

Die gevallestudies is volledig deur Oosthuizen (1993: 3-5) beskryf in terme van die kenmerke van die boerderyonderneming en die boer self, die organisasiestruktuur, personeelsamestelling, totale personeelgetal (tydelik, permanent en vroulik), ouderdomsverspreiding, skolastiese kwalifikasies, indiensopleiding en personeelomset. Die akronieme wat die gevallestudies voorstel, is gebaseer op die hoofboerderyvertakking (wat meer as $60 \%$ tot die bruto boerderyinkomste bydra), 'n letter van die betrokke provinsie en 'n let- ter van die distrik (Ficksburg en Paul Roux) om verdere onderskeid te tref, waar dieselfde hoofvertakkings in een provinsie voorkom. Die agt gevallestudies wat ontleed word, is MIELIES/T, PIESANG/T, TABAK/T, BOSBOU/N, SUIKER/N, KORING/V, VEE/VF en VEE/VPR. Die totale permanente personeelgetal $(n=234)$ wissel van 47 by MIELIES/T, 38 vir beide PIESANG/T en TABAK/T, 36 SUIKER/N, 28 BOSBOU/N, 19 VEE/VF en 14 vir beide KORING/V en VEE/VPR. Hul ouderdomme strek van 16 tot 67 jaar met 'n gemiddelde ouderdom van 36 jaar. Die werkers is oor die algemeen laaggeletterd met sowat die helfte van hulle wat geen skolastiese kwalifikasies het nie, ongeveer $45 \%$ met onderrig tot op laerskoolvlak en sowat $5 \%$ met 'n mate van hoërskoolopleiding. Die mate waarin werkers formele indiensopleiding ontvang het, verskil tussen die ondernemings en wissel van 10 tot $90 \%$ van die personeel, maar oor die algemeen kry minder as die helfte indiensopleiding. Die personeelomset is laag en wissel van 5 tot $12.7 \%$ per jaar vir die jongste vyfjaarperiode.

Aangesien die ouditprosedures en ontledingsmetodes vir die meting van PBD deur Oosthuizen (1993: 5-7) beskryf is, word gekonsentreer op die prosedures om PBE te evalueer. Die ouditprosedure bestaan uit ses stappe wat onder meer voorsiening maak dat die werkers 'n blok-en-penapparaat gebruik om die vrae wat ' $n$ instrukteur in hul taal oor PB aan hul stel, te beantwoord, terwyl die werkgewer drie toepaslike vraelyste moet voltooi (Oosthuizen \& Coetzee, 1991b: 20). Die een vraelys vir die werkgewer is die ouditvorm self waarop hy moet voorspel wat sy personeel se werkervaring en -voorkeure is en die ander vraelys is 'n ouditvorm waarin hy ' $n$ ondoeltreffende en doeltreffende PBS moet tipeer.

Die ouditvraelys bestaan uit 19 personeelbestuursfaktore wat in verband staan met leierskap, motivering, kommunikasie, menseverhoudinge, personeelbeheer en werkprestasie. Elke vraag bestaan uit twee dele waarvan die eerste deel oor die werker se werkervaring gaan en die tweede deel oor sy werkvoorkeure. Die respons word op 'n 20-punt Likert-skaal aangedui waar 1-5 tiperend is van 'n eksploiterende outoritêre personeelbestuurstelsel, 6-10 verteenwoordigend is van 'n welmenende outoritêre stelsel, 11-15'n konsulterende stelsel en 16-20 'n deelnemende PBS voorstel.

Die kriterium vir die vergelyking tussen die werkgewer en werknemers se mediaanpersepsies oor PB is Likert se vier personeelbestuurstelsels (Likert, 1961). Indien die verskil minder as een Likert stelsel is, is daar grootliks ooreenstemming tussen die werkers se persepsies en die werkgewer se voorspelling daarvan. Indien die verskil een stelsel is, is daar 'n geringe verskil; twee stelsels is 'n redelike verskil, en drie stelsels is 'n groot verskil. Die graadverskil tussen die personeel se werkervaringe en -voorkeure is met behulp van die mediaantoets by $95 \%$ betroubaarheid getoets.

\section{Resultate en bespreking van resultate}

Die werkers se persepsies oor die praktyke ten opsigte van leierskap, motivering, kommunikasie, menseverhoudinge, personeelbeheer en werkprestasie in elke van die agt ondernemings word met die boer se voorspellings daarvan in Tabel 1 vergelyk.

In al agt ondernemings ervaar die personeel in die geheel konsulterende personeelbestuurstelsels $(\mathrm{Me}=11-15)$ en word deur die boere dienooreenkomstig voorspel, maar die perso- 
Tabel 1 ' $n$ Vergelyking van die personeel se werkervarinqs (E) en werkvoorkeure $(V)$ en die boer se voorspelling daarvan ten opsigte van leierskap, motivering, kommunikasie, menseverhoudings, personeelbeheer en werkprestasie in agt boerdery-ondernemingstipes in Natal, die Oranje-Vrystaat en Transvaal, 1991

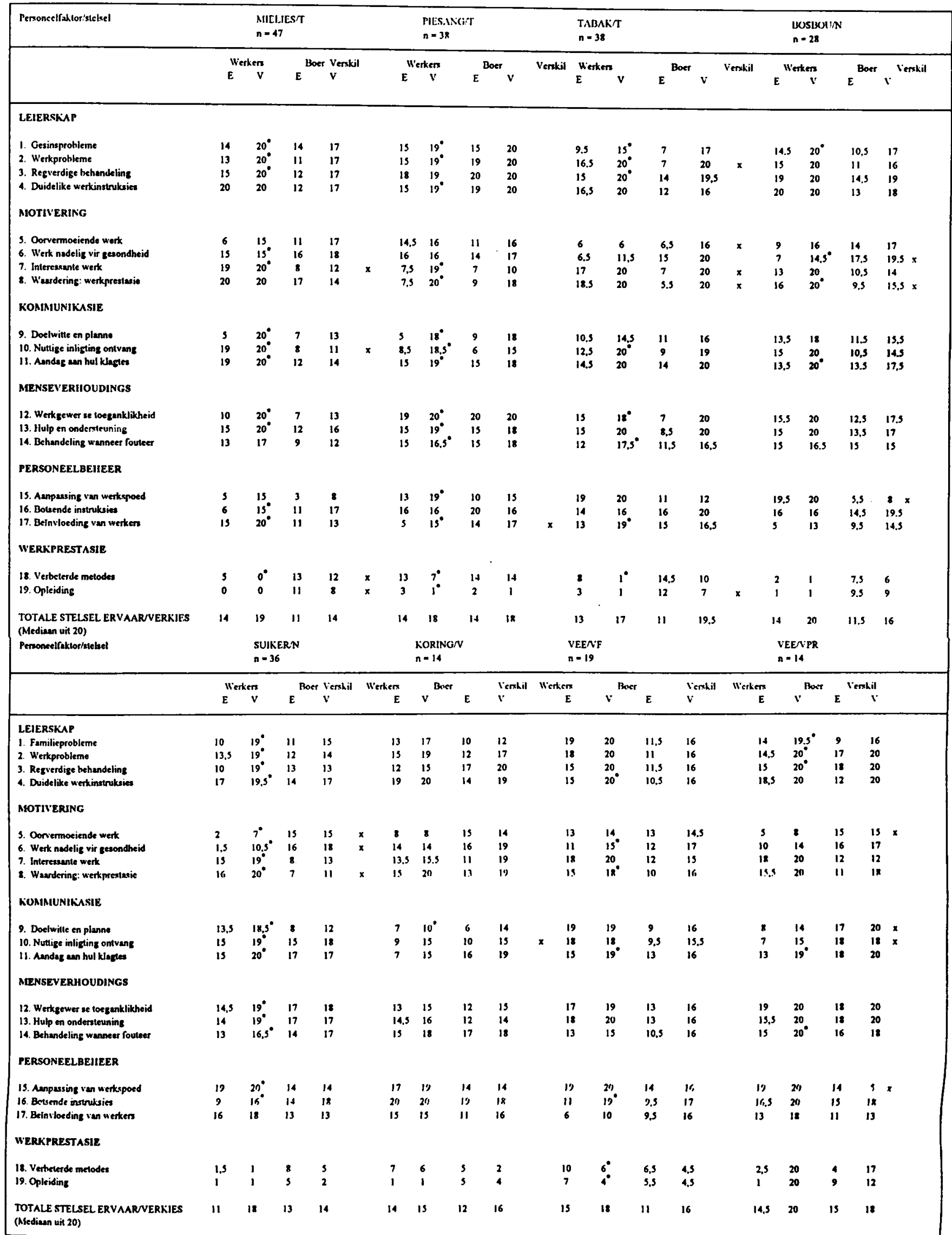

neel verkies in die gehee! deelnemende personeelbestuurstelsels (Me=16-20) met die uitsondering van een, KORING/V, waar die personeel 'n konsulterende PBS ervaar en verkies.
Wat die personeel se werkvoorkeure betref, het vyf boere korrek voorspel dat die personeel deelnemende personeelbestuurstelsels verkies, twee boere (MIELIES/T en SUIKER/N) 
het 'n konsulterende PBS voorspel en by KORING/V het die boer 'n deelnemende PBS voorspel terwyl die personeel 'n konsulterende PBS verkies.

By al agt gevallestudies is enersyds effektiewe personeelbestuurspraktyke gediagnoseer en kan situasionele personeclbestuursontwikkelingstrategieë geformuleer word om die produktiwiteit en werktevredenheid van die personeel binne elke onderneming te verbeter.

Met die nodige bestuurskennis, kan al agt boere die menseverhoudingstelsels in die ondernemings effektief bestuur. Die boere is dus in 'n voldoende mate bewus van die swak en sterk punte in die stelsels van menseverhoudinge. Effektiewe menseverhoudingspraktyke impliseer dat die boer in 'n groot mate besef wat die personeel se werkervarings en werkvoorkeure oor menseverhoudings in die werksituasie oor die algemeen is, sodat die personeel se werkgedrag gemanipuleer kan word ten einde groter produktiwiteit en werktevredenheid te verkry.

Die effektiwiteit van die motiveringstelsel is by vyf ondernemings (MIELIES/T, TABAK/T, BOSBOU/N, SUIKER/N en VEE/VPR) nie na wense nie, terwyl die werkprestasiestelsel by twee van die bogenoemde ondernemings (MIELIES/T en TABAK/T) asook KORING/V ruimte vir verbetering laat. Vervolgens is die effektiwiteit van die kommunikasiestelsels by vier ondernemings (MIELIES/T, KORING/V, VEE/VF en VEE/ VPR) nie na wense nie; die effektiwiteit van die personeelbeheerstelsels van drie ondernemings (PIESANG/T, BOSBOU/N en VEE/VPR) kan ook verbeter sowel as die effektiwiteit van die leierskapstelsel by TABAK $T$.
Die oneffektiwiteite in die personeelbestuurstelsels het betrekking op die geidentifiseerde swak en sterk punte in die personeelbestuurstelsels van die ondernemings. By MIELIES/T is vier oneffektiwiteite gediagnoseer waarvan almal met swak punte in die motivering-, kommunikasie- en werkprestasiestelsels in verband staan. By TABAK/T hou slegs een van die vyf gediagnoseerde oneffektiwiteite met 'n swak punt in die PBS verband. In SUIKER/N se geval het al drie oneffektiwiteite betrekking op swak punte in die motiveringstelsel. By BOSBOU/N is daar twee oneffektiwiteite ten opsigte van die motiveringstelsel wat as swak punte gediagnoseer is, terwyl die oneffektiwiteit in die personeelbeheerstelsel ten opsigte van 'n sterk punt is. By PIESANG/T het die oneffektiwiteit betrekking op ' $n$ swak punt in die personeelbeheerstelsel. Die oneffektiwiteite by VEE/VPR (motivering, kommunikasie en personeelbeheer), KORING/V (kommunikasie en werkprestasie) en VEE/VF (kommunikasie) staan in verband met sterk punte in die onderskeie personeelbestuurstelsels.

Die verskille tussen die werkers se persepsies oor $\mathrm{PB}$ en die boer se voorspellings dui op teenproduktiewe kragte wat reg. gestel moet word. Die uitgangspunt is nie wie se persepsies reg of verkeerd is nie maar waarom daar groot verskille bestaan. PB is 'n subjektiewe proses en 'n goeie bestuurder moet werkers se persepsies en gevolglik werkverhoudinge kan manipuleer ten einde hoër werkproduktiwiteit in die onderneming te bewerkstellig.

In Tabel 2 word die boere se persepsies betreffende doeltreffende en ondoeltreffende personeelbestuurspraktyke en -beleide in ' $n$ boerdery-onderneming vergelyk. Die doel hier-

Tabel 2 Die boere se persepsie betreffende doeltreffende (D) en ondoeltreffende (0) personeelbestuurspraktyke en -beleide in agt boerdery-ondernemingstipes in Natal, die Oranje-Vrystaat en Transvaal, 1991

\begin{tabular}{|c|c|c|c|c|c|c|c|c|c|c|c|c|c|c|c|c|}
\hline \multirow[t]{2}{*}{ Personeelfaklor/stelsel } & \multicolumn{2}{|c|}{$\begin{array}{l}\text { MIIELLIEST } \\
n=47\end{array}$} & \multicolumn{2}{|c|}{$\begin{array}{l}\text { PIESANG } T \\
n=38\end{array}$} & \multicolumn{2}{|c|}{$\begin{array}{l}\text { TABAK/T } \\
n=38\end{array}$} & \multicolumn{2}{|c|}{$\begin{array}{l}\text { BOSBOUN } \\
n=28\end{array}$} & \multicolumn{2}{|c|}{$\begin{array}{l}\text { SUIKERN } \\
n=36\end{array}$} & \multicolumn{2}{|c|}{$\begin{array}{l}\text { KORINGN } \\
n=14\end{array}$} & \multicolumn{2}{|c|}{$\begin{array}{l}\text { VEENF } \\
n=19\end{array}$} & \multicolumn{2}{|c|}{$\begin{array}{l}\text { VEENTR } \\
n=14\end{array}$} \\
\hline & D & 0 & D & 0 & D & 0 & D & 0 & D & 0 & D & 0 & D & 0 & $\mathrm{D}$ & o \\
\hline \multicolumn{17}{|l|}{ LEIERSKAP } \\
\hline 1. Familieprobleme & 13 & 3 & 19 & 8 & 15 & 3 & 14 & 8 & 17 & 7 & 10 & 3 & 16 & 8 & 18 & 3 \\
\hline 2. Werkproblerne & 14 & 4 & 17 & 9 & 20 & 9 & $\|$ & 5 & is & 6 & 15 & 8 & is & 8 & 18 & 5 \\
\hline 3. Regverdige bethendeling & 14 & 6 & 20 & 8 & 20 & 3 & 14 & 10 & 15 & 8 & 18 & 6 & is & 9 & 18 & 4 \\
\hline 4. Duidelike werkinstrukssies & 14 & 6 & 19 & 7 & 20 & 7 & 12 & 13 & 17 & 8 & 18 & 9 & is & 8 & 18 & 10 \\
\hline \multicolumn{17}{|l|}{ MOTIVERING } \\
\hline 5. Oorvermoeiende werk & 10 & 18 & 18 & 13 & 6 & 13 & 12 & 15 & 12 & 7 & 16 & 8 & 14 & 9 & 17 & 10 \\
\hline 6. Nadeligheid vir gesondheid & 13 & 9 & 19 & 20 & 10 & 10 & 11 & 14 & 17 & 14 & 16 & 10 & 14 & 11 & 17 & 14 \\
\hline 7. Interessunte werk & 8 & 1 & is & 3 & 13 & 4 & 10 & 4 & 14 & 10 & 16 & 9 & 12 & 7 & 17 & 8 \\
\hline 8. Erkenning vir prestusie & 14 & 2 & 16 & 2 & 20 & 3 & 9 & 6 & 18 & 8 & 19 & 6 & 13 & 9 & 17 & 3 \\
\hline \multicolumn{17}{|l|}{ KOMINIUNIKASIE } \\
\hline 9. Doelwitte en plarine & 14 & 3 & 15 & 3 & is & 1 & 14 & 6 & 18 & 9 & 16 & 8 & 14 & 7 & 17 & 2 \\
\hline 10. Nutrige inligting & is & 3 & 17 & 4 & is & 3 & 12 & 10,5 & 17 & 3 & 19 & 7 & 11 & $:$ & 18 & 5 \\
\hline II. Kbgieprosedure & 14 & 4 & 19 & 7 & 20 & $\bullet$ & 13 & 11 & 18 & 7 & 17 & 9 & 16 & 11 & 18 & 6 \\
\hline \multicolumn{17}{|l|}{ MIENSEVERIIOUDINGS } \\
\hline 12. Toeganklikheid & 14 & 2 & 20 & 9 & 15 & s & 13 & 7 & 16 & 8 & 16 & 6 & 19 & 9 & 19 & 6 \\
\hline 13. Hulp en onderteuning & 16 & 4 & 19 & 9 & 18 & 4 & 15 & 9 & is & $:$ & 18 & 8 & 14 & 8 & 18 & s \\
\hline 14. Behendeling wannoer forreer & 13 & 3 & 18 & 7 & 13 & 7 & 16 & 9 & 18 & 2 & 20 & 3 & 13 & 6 & 19 & 6 \\
\hline \multicolumn{17}{|l|}{ PERSONERLBEHEER } \\
\hline 15. Beheer oor werkeppoed & 16 & 3 & 14 & 2 & 13 & 7 & 9 & 6 & 17 & 2 & 18 & 8 & 15 & 8 & 18 & 6 \\
\hline 16. Botuende instruksies & 14 & 3 & $1:$ & 5 & 17 & 10 & 12 & 12 & 15 & 7 & 20 & 3 & 14 & 9 & 17 & 7 \\
\hline 17. Wedenydue invloed & 14 & 2 & 14 & $s$ & 13 & 12 & 7 & 13 & 14 & 14 & 19 & 8 & 13 & 6 & 2 & 16 \\
\hline \multicolumn{17}{|l|}{ WERKKPRESTASIE } \\
\hline 18. Verbeterde melodes & 18 & 4 & 9 & 5 & 13 & 3 & 13 & 3 & 14 & 3 & 2 & 16 & 5 & 14 & 1 & 16 \\
\hline 19. Opleiding & 4 & 17 & 10 & 3 & 8 & 18 & 10 & 3 & 3 & 2 & 1 & 14 & 7 & 14 & ; & is \\
\hline TOTALE STELSEL & 14 & $\mathbf{3}$ & 18 & 7 & 15 & 7 & 12 & 9 & 16 & 7 & 17 & 8 & 14 & 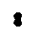 & 18 & 6 \\
\hline
\end{tabular}


van was om potensiële kennisleemtes in PB by hierdie boere te diagnoseer en moontlike verklarings te kry vir geïdentifiseerde swak punte in die PBS.

Die helfte van die boere (PIESANG/T, SUIKER/N, KORING/ $\checkmark$ EN VEE/VPR) tipeer ' $n$ deelnemende PBS $(\mathrm{Me}=16-20)$ as 'n doeltreffende stelsel vir ' $n$ hoëproduksie-onderneming terwyl die ander vier boere (MIELIES/T, TABAK/T, BOSBOU/N en VEE/VF) ' $n$ konsulterende PBS $(\mathrm{Me}=11-15)$ in verband bring met ' $n$ hoëproduksie-onderneming.

Outoritêre personeelbestuurspraktyke wat as doeltreffend beskou word, is motivering (MIELIES/T, TABAK/T en BOSBOU/N), personeelbeheer (BOSBOU/N en VEE/VPR) asook werkprestasie by al agt ondernemings.

Oor die algemeen beskou die boere 'n outoritêre PBS as tiperend van 'n lae-produksie-onderneming. In sewe ondernemings word ' $\mathrm{n}$ welmenende outoritêre PBS $(\mathrm{Me}=6-10)$ as 'n ondoeltreffende stelsel getipeer, terwyl een boer (MIELIES/T) 'n eksploiterend-outoritêre PBS (Me=1-5) as ondoeltreffend tipeer.

Deelnemende personeelbestuurspraktyke wat as ondoeltreffend beskou word, is Herzberg se higiëne faktore (MIELIES/T en PIESANG/T), personeelbeheer (VEE/VPR) en werkprestasie (MIELIES/T, TABAK/T, KORING/V en VEE/VPR).

Die boere se persepsies oor die rol van opleiding (faktor 19) in 'n produktiewe/onproduktiewe onderneming kan 'n knelpunt word in die ontwikkeling van produktiwiteitstrategieë vir die ondernemings. Die boere se uitgangspunt dat die opleiding van werkers in 'n onproduktiewe onderneming die werkers glad nie of slegs in ' $n$ geringe mate sal help om hul werk beter te doen, is teenstrydig met Likert se teorie.

Aangesien die personeel in sewe ondernemings deelnemende personeelbestuurstelsels verkies, sal die vier boere (MIELIES/T, TABAK/T, BOSBOU/N en VEE/VF) wat 'n konsulterende PBS as tiperend van ' $n$ produktiewe onderneming beskou, hul bestuursaannames moet hersien. Indien werkgewers konsekwent deelnemende personeelbestuurstelsels implementeer, sal die personeel volgens die selfvervullende profesie oor die lang termyn ' $n$ deelnemende PBS ervaar wat tot groter werkerproduktiwiteit en werknemertevredenheid behoort te lei.

\section{Gevolgtrekking}

Oor die algemeen kan die gevallestudieboere, gegewe die nodige bestuurskennis, die menseverhoudingstelsels in die ondernemings effektief manipuleer aangesien die personeel se werkervarings en -voorkeure ten opsigte van menseverhoudinge in 'n groot mate ooreenstem met die werkgewer se voorspellings daarvan.

Die effektiwiteit van die praktyke en beleide met betrekking tot motivering, kommunikasie, werkprestasie, personeelbeheer en leierskap laat ruimte vir verbetering.

Die gevallestudieboere se kennis ten opsigte van doeltreffende teenoor ondoeltreffende personeelbestuurstelsels kan heelwat verbeter. Hulle persepsies oor die rol van opleiding in 'n onproduktiewe onderneming verklaar in 'n groot mate die swak punte in die werkprestasiestelsels van die gevallestudies.

Alhoewel die doel van die PBO is om PBD en PBE binne 'n enkele onderneming te meet en nie tussen ondernemings nie, en die gevallestudies geselekteer is wat nie die gemid- delde onderneming betrek het nie, is daar tekens van 'n uniforme personeelbestuursbenadering en behoort vasgestel te word hoe algemeen konsulterende personeelbestuurstelsels op plase voorkom, terwyl die personeel deelnemende PBS verkies. Indien hierdie tendens universeel voorkom, beteken dit dat PBD en PBE op Suid-Afrikaanse plase oor die algemeen heelwat kan verbeter deur meer deelnemende stelsels te implementeer.

\section{Erkenning}

Geldelike bystand deur die Universiteit van die OranjeVrystaat (UOVS) word vir hierdie navorsing erken, maar die menings is die van die outeur en word nie noodwendig deur die UOVS onderskryf nie.

Die outeur bedank die volgende persone se waardevolle bydraes in die uitvoering en ontledings van die oudits: Mevv. T. Kühne, en M. Labuschagne asook mnre. B. Ndaba, M.K. Bodenstein, T. Qwabe, A. Faul, J. Morwane, P.J. Strydom, S.Baloyi, C.J. du Plessis, D. Mashinini en M.A. Radeke.

\section{Summary}

Personnel management efficiency and effectiveness in a business can be quantified by means of a diagnostic instrument such as the Likert-type personnel management audit (PMA). The PMA is a technique that is conducted with the aid of the case-study method. In the first place it entails the quantification of the perceptions of staff in the business to the lowest level of literacy - regarding personnel management (PM), in a practical and reliable manner; second, the perceptions of the employer on PM must also be measured in order to determine how effectively the employer can manipulate the employees' work behaviour; and third, a systems approach must be followed in diagnosing the personnel management system (PMS).

The aim of this study was, first of all, to establish the degree of discrepancy between the work experiences and work preferences of the personnel on the one hand, and the prediction of the employer in this regard, on the other; and second, to analyse the employer's perceptions on efficient versus inefficient personnel management practices.

A PMA was conducted at eight different farming businesses, located over a wide area in the RSA. The farming businesses include maize farming in the Transvaal (MAIZE/T), bananas in the Northern Transvaal (BANANAS/T), tobacco in the Western Transvaal (TOBACCO/T), forestry in Natal (FORESTRY/N), sugar cane in Natal (SUGAR/N), wheat in the Central Free State (WHEAT/F), livestock in the Ficksburg district in the Eastern Free State (LIVESTOCK/FF) and livestock in the Paul Roux district in the Eastern Free State (LIVESTOCK/ FPR).

The total number of permanent staff members $(n=234)$ varied from 47 in MAIZE/T, 38 for both BANANAS/T and TOBACCO/T, 36 for SUGAR/N, 28 FORESTRY/N, 19 LIVESTOCK/FF, and 14 for both WHEAT/F and LIVESTOCK/FPR. The ages of the workers varied between 16 to 67 years; they mostly had a low level of literacy, and more than half of them did not receive formal in-service training.

The audit procedure comprises six steps that inter alia make provision for the workers to use a block-and-peg apparatus to respond to the questions on PM, put to them in their 
own language by an instructor, while the employer has to complete three applicable questionnaires (Oosthuizen \& Coetzee, 1991: 20). The one questionnaire for the employer is the audit form, in which he has to predict his workers' work experiences and preferences, and the other is an audit form on which he has to typify an inefficient and an efficient PMS.

The audit questionnaire comprises 19 personnel management factors, related to leadership, motivation, communication, human relations, staff control, and work performance. Each question consists of two parts, the first of which deals with the worker's work experience and the second part deals with his/her work preferences. The responses are indicated on a 20-point Likert scale, where 1-5 is typical of an exploitive authoritative PMS, 6-10 represents a benevolent authoritative PMS, 11-15 is indicative of a consultative system and 16-20 of a participative PMS.

The criterion for the comparison of the median perceptions of PM of the employer and the employees is the four systems of Likert. A discrepancy to the equivalent of two Likert systems $(1-10)$ or more is used to diagnose an inefficient management practice. The degree of discrepancy between the work experience and preferences of the workers is tested by means of a median test at $95 \%$ significance. In all eight the case studies effective management practices as well as ineffective practices were identified. Thus situational staff management development strategies can be formulated to improve the productivity and worker satisfaction in each of the businesses.

In general the effectiveness of the motivation, communication, work performance, staff control and leadership systems leaves room for improvement. The knowledge of the farmers in the case-studies as regards efficient and inefficient PMS can be improved considerably, especially their perceptions of the role of training in worker productivity and work satisfaction. With the necessary knowledge of management, the farmers will be able to manipulate the human relations practices effectively.

It ought to be determined to what extent consultative PMS is utilized on farms, while the staff members prefer participative PMS. If this is a universal trend, it has the implication that personnel management efficiency and effectiveness on farms in the RSA in general can be improved considerably by implementing participative PMS.

\section{Veruysings}

Antrobus, G.G. 1984. South African farm wages and working conditions, with special reference to the Albany district 1957-
1977. Proefskrif (D.Phil) Universiteit van Rhodes. Grahamstad.

Armstrong, J. \& Lloyd, D.H. 1972. Staff management audit. A system for evaluating the staff management processes in agricultural organisations. Study no. 12. Reading: University of Reading, Department of Agriculture.

Beyers, J.P. 1971. Farm labour in Western Cape. Proefskrif (Ph.D.) Universiteit van Kaapstad, Kaapstad.

Du Toit, H. 1982. Plaasarbeid in die Frankfort-distrik.

M.A.verhandeling. Universiteit van Stellenbosch, Stellenbosch.

Graham, J.D. \& Groenewald, J.A. 1969.

'Doeltreffendheidsvergelykings tussen melkportale en -skure', Agrekon, Vol. 8, Nr. 4:11-17.

Hill, J.N.S. 1974. Modernisation of management techniques in large agricultural operations. Proefskrif (D.Sc.Agric). Universiteit van Pretoria, Pretoria.

Kassier, W.E. 1964. "n Arbeidsbegrotingsmetode met spesiale verwysing na toestande in Natal', Agrekon, Vol. 3, Nr. 2:25-30.

Kassier, W.E. 1966. 'A production function study of marginal returns and optimum intensity on East Griqualand farms', South African Journal of Economics, Vol 31. Nr. 2: 118-126.

Likert, R. 1961. New patterns of management. New York: McGraw Hill, 279p.

Louw, P.G. 1969. ' $n$ Ondersoek na arbeidsprobleme vir wynboere in Wes-Kaapland. MA-verhandeling. Universiteit van Stellenbosch, Stellenbosch.

Oosthuizen, L.K. 1990. 'Die ontwikkeling van 'n diagnostiese instrument vir die meting van personeelbestuur in ontwikkelende lande', Agrekon, Vol. 29, Nr. 2: 113-121.

Oosthuizen, L.K. \& Coetzee, L. 1991a. "n Diagnose van die personeelbestuurstelsel in 'n boerdery-onderneming', Agrekon, Vol. 30 , Nr. 2: 61-73.

Oosthuizen, L.K. \& Coetzee, L. 1991b. "n Vergelyking tussen 'n boer en sy personeel se persepsies oor personeelbestuursdoeltreffendheid en -effektiwiteit in die boerderyonderneming', SuidAftikaanse Tydskrif vir Landbouvoorligting, Vol. 20: 18-27.

Oosthuizen, L.K. \& Radley, A.J. 1991. Die meting van personeelbestuur in 'n boerdery-onderneming. Agrekon, Vol. 30, Nr. 1: 18-28.

Oosthuizen, L.K. 1994. 'A comparison of the perceptions of farm workers on personnel management efficiency in nine farm business types in the RSA', Agrekon, Vol. 33, Nr. 3: 96-100.

Parsons, S.D. 1978. 'Organisasie en delegasie: bestuur van die ondernemer se tyd', Agrekon, Vol. 17, Nr. 2: 15-18.

Robertson, B.J. 1989. An economic study of farm labour in the Lions River, Lower Tugela and Elliot magisterial districts. M. Sc.Agric. M.A.-verhandeling. Universiteit van Natal, Pietermaritzburg.

Roodt, G. 1980. ' $n$ Ondersoek na personeelbestuur in die saaiboerderybedryf. Bloemfontein: Universiteit van OranjeVrystaat. Departement Bedryfsielkunde. (Nr.P/26).

Wilson, F., Kooy, A. \& Hendrie, D. (eds.). 1977. Farm Labour in South Africa. Cape Town: David Phillip. 